Uniwersytet Rolniczy im. H. Kołlątaja w Krakowie Instytut Ekonomiczno-Społeczny

\author{
Agnieszka Piotrowska \\ Jacek Puchała
}

\title{
MOTYWOWANIE JAKO FUNKCJA ZARZĄDZANIA W OBRĘBIE PRZEDSIĘBIORSTWA
}

Z a ry s tre ś c i. Struktura motywów ma zawsze układ hierarchiczny. Oznacza to, że jedne wartości cenione są przez pracowników bardziej, inne trochę mniej. Powstaje osobista hierarchia potrzeb, dla każdego człowieka różna, gdyż różne osoby cenią różne wartości, przy czym ludzie preferują te wartości, które są przez nich najbardziej cenione i jednocześnie te, które uznają za najbardziej realne do osiągnięcia. $\mathrm{W}$ artykule podjęto próbę określenia wartości systemu motywowania $\mathrm{w}$ badanym przedsiębiorstwie. W tym celu przeprowadzono badania ankietowe. Podjęto również próbę określenia stosunków, jakie panują między pracownikami, oraz jakie czynniki motywacji materialnej i niematerialnej są najważniejsze dla badanych pracowników.

Słow a kluc zow e: motywacja, zarządzanie, dwuczynnikowa teoria F. Herzberga.

\section{WSTĘP - CEL, METODYKA}

Zajęcie się problematyką motywacji oznacza poszukiwanie czynników sterujących poziomem gotowości i aktywizacji organizmu, jakim jest przedsiębiorstwo. Warto badać czynniki, które powodują, że człowiek wykazuje skłonność do pewnych form zachowania, które są korzystne dla właściciela firmy. Stąd ważne jest postawienie pytania: jakie zdarzenia będą wzmocnieniem pozy- 
tywnych zachowań w procesie uczenia się organizacji oraz jak daleko efektywne okażą się te wzmocnienia dla przedsiębiorstwa. Ze względu na fakt, że poszczególni pracownicy realizują różne cele osobiste i organizacyjne, mają odmienne umiejętności i warunki pracy, organizacja, pragnąc realizować swój cel, powinna elastycznie posługiwać się w procesie motywowania szerokim spektrum środków oddziaływania na motywy postępowania pracowników (Karaś, 2003).

Istnieje wiele firm na polskim rynku różniących się nie tylko wielkością, ale także kulturą organizacyjną i podejściem do pracownika jako do człowieka. Motywacja do pracy jest niekiedy tylko pustym sloganem. Wszystko dzieje się na zasadzie płacę - wymagam. Poruszając problem motywacji, ludzie często odpowiadają, że motywuje ich tylko wyższe wynagrodzenie za pracę. Każdy chciałby zarabiać więcej, jednak ciągle zwiększanie wynagrodzenia nie prowadzi do wydajniejszej pracy. Motywacyjna rola pieniądza nie polega na oddziaływaniu jego ilością, lecz raczej na oddziaływaniu składnikami wynagrodzenia. W odczuciu pracowników musi istnieć współzależność pomiędzy wielkością otrzymywanych korzyści a nakładami starań i osiąganymi wynikami w pracy (Zbiegień-Maciąg, 1997).

Motywowanie ma podstawowe i zarazem bardzo istotne znaczenie dla współczesnego zarządzania zasobami ludzkimi. Zwiększa ono sprawność, skuteczność oraz wydajność, a także prawdopodobieństwo realizacji wytyczonych celów przedsiębiorstwa. W odwrotnej sytuacji zwiększa się czasochłonność zarządzania, potrzebna jest nieustanna kontrola, narastają konflikty i ogólny chaos w przedsiębiorstwie (Machaczka, 1999).

Brak motywacji w grupie pracowników może przyczynić się do występowania szkodliwych tendencji. Ich przykładem mogą być: zwiększona liczba nieobecności pracowników, marnowanie czasu na przerwy, działanie na szkodę firmy, biurokracja, zmniejszenie staranności, zmniejszenia tempa pracy, zmniejszenie kreatywności, zmniejszenie chęci brania na siebie odpowiedzialności. Każdy kierownik musi być świadomy tego, że jego zadaniem jest wywieranie wpływu na swoich podwładnych (Bruce, Pepitone, 2001).

Dorobek teoretyczny w zakresie wyjaśniania motywacji ludzi do pracy jest znaczny i niejednolity. Systematyzując poglądy na naturę motywacji do pracy, można wyróżnić trzy grupy teorii: teorie treści, teorie procesu, teorie wzmocnienia (Lubrańska, 2008). Według A. Maslowa istnieje 5 grup potrzeb, umieszczonych na 5-poziomowej piramidzie. Człowiek po zaspokojeniu potrzeb na niższym poziomie zwraca uwagę na potrzeby z kolejnego, wyższego poziomu. Stwierdza on, że podstawowym wewnętrznym czynnikiem motywacyjnym są: Potrzeby fizjologiczne - odżywiania się, przetrwa- 
nia, wody, tlenu i snu. Potrzeba bezpieczeństwa pojawia się w momencie, gdy potrzeby fizjologiczne zostaną zaspokojone, koncentrując uwagę na zapewnieniu sobie bezpieczeństwa, oddaleniu wszelkich zagrożeń, stabilności, porządku oraz sprawiedliwości (Gick, Tarczyńska, 1999). Po pewnym czasie człowiek odczuwa pragnienie odnoszące się do relacji z innymi ludźmi, bycia kochanym, przynależności do grupy - potrzeby społeczne. Niezaspokojenie ich prowadzi do zamknięcia się w sobie i samotności, które mogą się pogłębiać, doprowadzając do wyobcowania, co często jest skutkiem negatywnego funkcjonowania człowieka w miejscu pracy oraz jego efektywności (Sikora, 2000). Na następnym poziomie pojawia się potrzeba osiągnięć, prestiżu i uznania w miejscu pracy, ważne jest, by inni dostrzegli profesjonalizm. Na szczycie ludzkich potrzeb według Maslowa jest samorealizacja. Na tym najwyższym poziomie ludzie koncentrują swoją uwagę na potrzebach wykorzystaniach własnego potencjału i osiągnięciu celów, satysfakcję przynosi zaspokojenie osobistych ambicji. W przeciwieństwie do wcześniejszych potrzeb potrzeba samorealizacji nigdy nie zostaje w pełni zaspokojona (Karaś, 2003).

Następnym ważnym fundamentem praktycznej pracy kierowników może być dwuczynnikowa teoria Fredericka Herzberga. Podstawowym założeniem tej teorii jest stwierdzenie, że na zadowolenie ludzi z pracy mają wpływ dwie niezależne kategorie czynników. Mianowicie są to: czynniki higieny zwane zewnętrznymi orz czynniki motywacyjne - wewnętrzne. Pierwsza z grup dotyczy środowiska pracy, czyli wynagrodzenia, bezpieczeństwa i warunków pracy, relacji międzyludzkich w środowisku pracy czy też dodatkowych korzyści z pracy. Jeśli nie osiągną one wystarczającego poziomu, wówczas spowodują poczucie niezadowolenia z pracy. Druga grupa czynników motywacyjnych związana jest z poczuciem satysfakcji. Jej źródłem mogą być: potrzeba osiągnięć, uznanie, zakres odpowiedzialności, możliwość własnego rozwoju. Na zadowolenie z pracy wpływa druga grupa czynników, pierwsza zaś rodzi uczucie niezadowolenia. Zatem teoria ta mówi, że na początku kierownicy powinni zlikwidować niezadowolenie, czyli zapewnić swoim podwładnym odpowiednią płacę oraz warunki pracy, a dopiero później wzbudzać w nich motywacje i zadowolenie (Gliszczyńska, 1991).

Celem badań było określenie jakości systemu motywowania funkcjonującego w przedsiębiorstwie. Podjęto również próbę określenia stosunków interpersonalnych, jakie panują między badanymi pracownikami, oraz jakie czynniki motywacji materialnej i niematerialnej są najważniejsze dla badanych pracowników. Aby zbadać system motywacyjny w tym przedsiębiorstwie, przeprowadzono badania ankietowe wśród 50 pracowników spośród 
74 zatrudnionych. Ankieta była anonimowa i została przeprowadzona w lipcu 2010 roku.

\section{OGÓLNA CHARAKTERYSTYKA FIRMY}

Analizowana firma powstała w 2001 roku. Przedsiębiorstwo zatrudnia ponad 70 osób, a w 2007 roku zdobyło wyróżnienie w konkursie „Firma równych szans" za politykę równego dostępu do awansu. Produkty firmy dostępne są w sprzedaży detalicznej w sieciach sklepów z branży: IT, Foto-Video, RTV oraz wielu innych. W skład oferty firmy wchodzą płyty CD i DVD, akcesoria komputerowe i sieciowe, produkty czyszczące oraz różnego rodzaju opakowania marek. Przedsiębiorstwo w ciągu kilku lat zdobyło pozycję lidera wśród dystrybutorów nośników danych oraz akcesoriów komputerowych. Obsługuje grupę kilku tysięcy klientów na całym świecie, w tym sieci supermarketów i hipermarketów. Potwierdzeniem dotychczasowych sukcesów są Gazele Biznesu 2005, 2006 i 2007 - nagroda dla przedsiębiorstw, które osiągają bardzo dobre wyniki finansowe, dynamicznie rozwijają się oraz są rzetelnymi partnerami biznesowymi. Ponad połowa całkowitej sprzedaży towarów znajduje nabywców za granicą, co pozwala zaliczyć to przedsiębiorstwo do czołówki polskich eksporterów. Według rankingu eksporterów Home \& Market firma zajęła pierwsze miejsca w kategoriach: wzrost eksportu, wzrost przychodów z eksportu oraz rentowność kapitałów własnych w 2005 roku.

W badaniu wzięło udział 50 pracowników przedsiębiorstwa. Wśród badanych pracowników 32\% stanowiły kobiety, a 68\% mężczyźni. Wynika to z faktu, że na stanowiskach wykonawczych większość pracowników to magazynierzy. Kobiety wykonujące pracę fizyczną zatrudnione są jedynie w dziale konfekcji. Wśród stanowisk nierobotniczych również częściej zatrudnienie znaleźli mężczyźni, ponieważ w działach sprzedaży konieczna jest znajomości asortymentu, jego specyfikacji technicznej i przeznaczenia, a specjaliści branży IT w naszym kraju to w przeważającej liczbie mężczyźni. Kobiety stanowią z kolei większość w takich działach jak księgowy, finansowy czy personalny. 


\section{METODY MOTYWOWANIA PRACOWNIKÓW W BADANYM PRZEDSIĘBIORSTWIE}

W ankiecie pytano respondentów o ich stosunek do pracy. Ankietowane kobiety (32\% pań) dały odpowiedź twierdzącą. W grupie badanych $24 \%$ uważa, że czynnikiem który umożliwia oddziaływanie na pracownika w sposób pozytywny, jest możliwość samorealizacji i odpowiednie wynagrodzenie za pracę $-8 \%$. Natomiast $68 \%$ badanych kobiet uznało, że nie lubi swojej pracy, a jako czynniki demotywujące wskazało brak możliwości samorealizacji (38\% pań), oraz nieodpowiednie wynagrodzenie za prace (30\% wskazań). Gdyby jednak podzielić odpowiedzi kobiet według rodzaju zajmowanego stanowiska, otrzymamy zupełnie inne zestawienie. Okazuje się, że wszystkie kobiety pracujące na stanowiskach umysłowych odpowiedziały, że praca pozwala im wykorzystać swój potencjał, a 33\% z nich uważa, że jest odpowiednio opłacana za swoją pracę. Wszystkie badane kobiety na stanowiskach wykonawczych uważają, że nie mają możliwości samorealizacji w pracy, a $75 \%$ z nich uważa, że otrzymuje za wykonywaną pracę nieodpowiednie wynagrodzenie. Powyższe wyniki wskazują, że dla objętych badaniem kobiet zajmujących stanowiska nierobotnicze praca stanowi wyzwanie, czują się spełnione i z pewnością chętnie przychodzą do pracy. Można też uznać, że znajdują się na szczycie potrzeb piramidy A. Maslowa. Kobiety wykonujące pracę fizyczną swoją pracę oceniają negatywnie, żadna z nich nie spełnia się zawodowo, a 75\% pań narzeka na zarobki. Wszystkie ankietowane kobiety pracujące fizycznie równocześnie podejmują naukę. Praca, którą wykonują, jest jedynie tymczasowa, pozwala im przetrwać do osiągnięcia takiego wykształcenia, które pozwoli im podjąć pracę na innym, bardziej odpowiadającym im stanowisku.

Badani mężczyźni nieco inaczej wyrażali swoją opinię odnośnie, stosunku do swojej pracy. Tylko $20 \%$ ankietowanych mężczyzn dało odpowiedź twierdzącą, wskazując, że lubi swoją pracę. Wśród nich 12\% wskazało tak ze względu na możliwość samorealizacji, a $8 \%$ ze względu na dobre zarobki.

Swojej pracy nie lubi aż 80\% ankietowanych, jako demotywatory wskazując złe zarobki - 38\% i brak możliwości samorealizacji (42\% panów). Wśród mężczyzn podobnie jak wśród kobiet wyniki dotyczące braku samorealizacji występują głównie u osób uczących się, traktujących pracę jako tymczasową, która ma zapewnić środki do życia. Motywację do pracy znajdują w chęci zaspokojenia potrzeb znajdujących się na niższych szczeblach piramidy A. Maslowa, takich jak potrzeba jedzenia czy mieszkania. 
Stosunki interpersonalne w badanej firmie były tematem kolejnego pytania. Wszystkie badane kobiety i 95\% ankietowanych mężczyzn określiło je jako koleżeńskie. Jest to duży atut przedsiębiorstwa, gdyż coraz więcej ludzi ceni sobie odpowiednie traktowanie i dobrą atmosferę w pracy. Na motywację do pracy mają wpływ stosunki interpersonalne w przedsiębiorstwie i opisywany przypadek nie jest od tej reguły wyjątkiem. Obrazuje to odsetek wskazań na znaczenie relacji międzyludzkich dla motywacji do pracy. Dla co czwartego respondenta jest on bardzo duży, duży - dla 44\% pytanych, znaczący $-16 \%$ badanych, niewielki - jedynie dla $16 \%$ osób. Niewielki wpływ na motywację wskazali pracownicy którzy wcześniej określali swoją pracę jako słabo opłacaną i uniemożliwiającą ich samorealizację. Interpretując uzyskane wyniki zgodnie z teorią F. Herzberga, można powiedzieć, że nie wszystkim zostały zapewnione czynniki higieny, które związane są z warunkami wykonywania pracy. Są w badanej grupie osoby o znikomej motywacji do pracy, traktujące ją jako przymus. Są one zwykle niezadowolone i sfrustrowane. Motywowanie takich pracowników jest bardzo trudne. Wśród osób, które w ankiecie wskazały na duży lub bardzo duży wpływ relacji między pracownikami na motywację, $66 \%$ stanowią pracownicy umysłowi, a $34 \%$ to pracownicy wykonawczy.

Prawie co dziesiąty ankietowany (8\%) to osoba z wykształceniem zawodowym, ponad połowa badanych (54\%) to osoby z wyższym wykształceniem. Wykształcenie wiąże się tu z rodzajem wykonywanej pracy i poziomem w hierarchii społecznej. Pracownicy z wyższym wykształceniem pracują na wyższych w hierarchii zarządzania stanowiskach. W ich przypadku podstawowe potrzeby już nie motywują, stąd dużą wagę przywiązują do atmosfery w pracy.

Stosunki z przełożonymi są ważnym czynnikiem motywującym do pracy w badanej firmie (wykres 1). Wszyscy ankietowani udzielili odpowiedzi potwierdzającej wpływ relacji z kierownictwem na chęć do pracy. Dla co czwartego z ankietowanych wpływ ten jest bardzo duży, dla co piątego duży. Niewielki wpływ relacji z przełożonymi na motywację do pracy odczuwa jedynie $20 \%$ ankietowanych. Uzyskane wyniki wskazują, iż atmosfera w pracy jest bardzo ważnym elementem motywującym. Mimo że skala odpowiedzi była szeroka, od bardzo dużego do niewielkiego wpływu tych relacji na motywację, to trzeba podkreślić, że dla $80 \%$ pytanych relacje z przełożonym są ważnym motywatorem. 


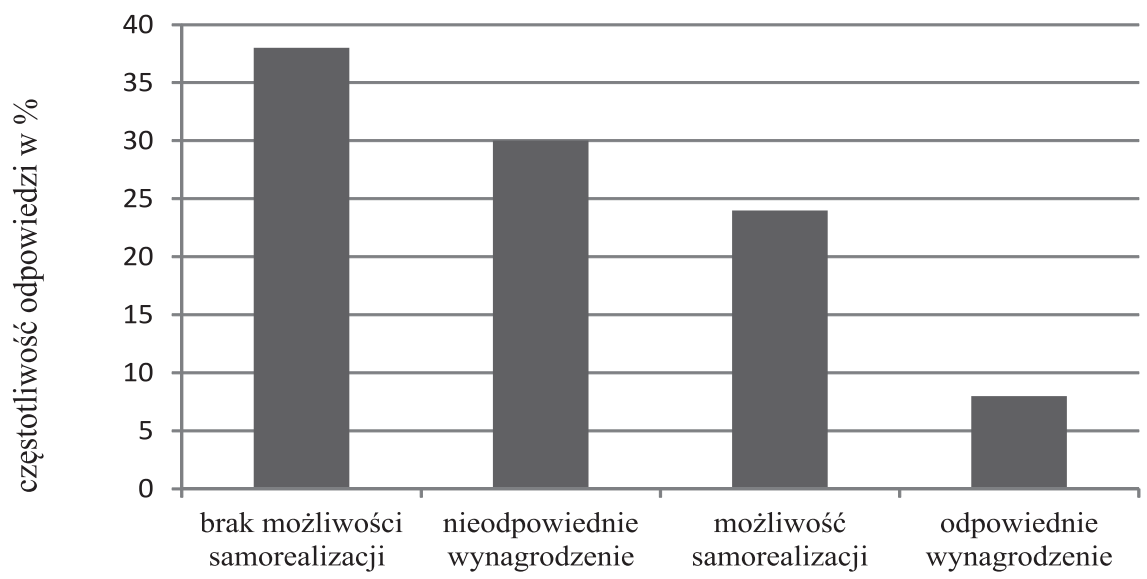

Wykres 1. Opinie badanych pracowników o wykonywanej pracy

Źródło: badania własne.

W dalszej części ankiety zadano pytanie dotyczące preferowanych przez ankietowanych form motywacji materialnej. Każdy badany mógł zaznaczyć do trzech odpowiedzi spośród sześciu propozycji. Największą liczbę wskazań otrzymała odpowiedź premia - 44\%, przy czym wszystkie panie i ośmiu z dziesięciu (84\%) mężczyzn wskazało premię jako jedną z najważniejszych form motywacji materialnej. Udział w zyskach jako premię preferuje jeden na pięciu badanych. Premia po przekroczeniu określonego poziomu osiągnięć motywuje $15 \%$ pracowników. Ankietowani mniej niż wcześniej omawiane motywatory cenią nagrody za innowacje (11\% wskazań), upominki rzeczowe (7\% wskazań), a najmniej doceniane są premie za kwalifikacje (jedynie 4\% wskazań). Otrzymane wyniki wskazują, że najbardziej motywują premie i nagrody finansowe. Potwierdza się również teoria, iż pracownicy bardziej cenią nagrody, które można zdobyć szybko. Premia za kwalifikacje, której osiągnięcie wiąże się z uzupełnieniem wykształcenia bądź kursu, jest procesem długotrwałym, często trwającym kilka lat, przez co była najrzadziej wymieniana jako efektywny motywator. Tylko 7\% wskazań na motywatory dotyczyło upominków rzeczowych. Może to wskazywać na małą wartość dotychczasowych nagród. Pracownicy wprost stwierdzili, że zbyt często upominki rzeczowe miały dla nich niską wartość i uznali je za mało efektywną formę motywacji.

Dane na wykresie 2 przedstawiają preferencje pracowników badanej firmy oraz formy motywowania materialnego stosowane w przedsiębiorstwie. 
Pracownicy, odpowiadając na pytanie, mieli za zadanie wymienić dostrzegane przez nich sposoby motywowania stosowane w badanej firmie. Co trzecia osoba z grupy pięćdziesięciu badanych pracowników uznała, że nie występuje $\mathrm{w}$ ich przedsiębiorstwie żadna $\mathrm{z}$ form motywowania materialnego, zatem nie dostrzegają lub nie znają lokalnej specyfiki systemu motywacyjnego. Takie osoby są równocześnie $\mathrm{w}$ grupie pracowników niezadowolonych z pracy. Odnosząc ten fakt do teorii motywacji F. Herzberga, można powiedzieć, że być może nie zostały usunięte czynniki prowadzące do niezadowolenia z pracy.

Najczęściej wskazywaną formą motywowania materialnego były udziały w 33\% wskazań, podwyżka (17\% głosów) oraz udziały w zyskach (13\% opinii). Materialnym motywatorem rzadko są upominki rzeczowe i nagrody za innowacje (odpowiednio 4 i 3\% wskazań). Premia za kwalifikacje nie została uznana za motywator przez żadnego z pracowników.

Formy motywowania występujące w przedsiębiorstwie są w znacznej części zgodne z tym, czego pracownicy oczekują. Najczęściej stosowane formy motywacji w badanym przedsiębiorstwie są równocześnie najbardziej oczekiwane przez pracowników. Niektóre jednak z motywatorów są bardziej pożądane od pozostałych - środki finansowe nakierowane na motywowanie pracowników można lepiej zagospodarować. Oznacza to, iż system motywacji materialnej w przedsiębiorstwie wymaga jednak korekty, które zbliżyłyby ten system do systemu oczekiwanego przez pracowników.

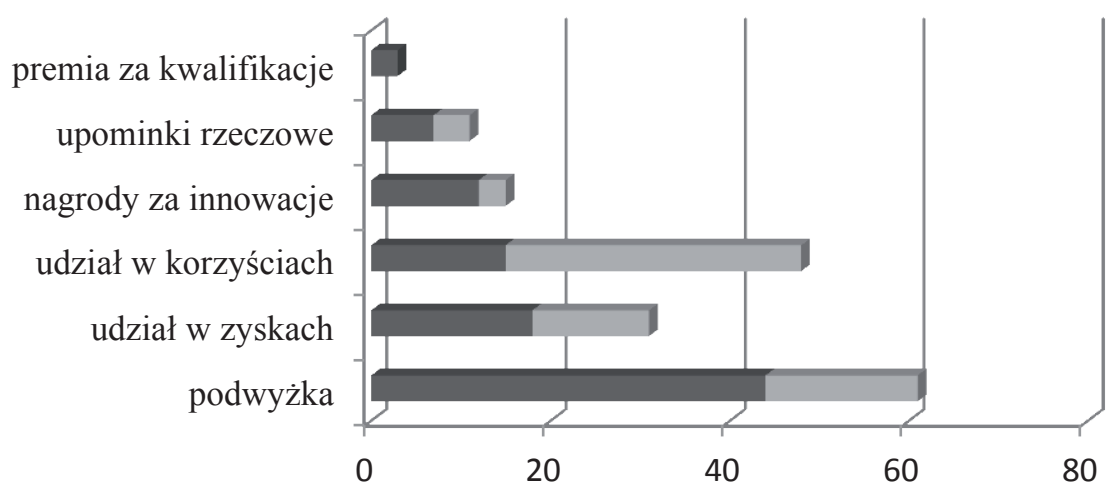

Częstotliwość odpowiedzi w \%

Wykres 2. Najważniejsze czynniki motywacji materialnej dla badanych pracowników $\mathrm{i}$ formy motywacji stosowane $\mathrm{w}$ badanym przedsiębiorstwie

Źródło: badania własne. 
W wyniku badań przeprowadzonych w przedsiębiorstwie stwierdzono, że preferowanymi przez pracowników formami motywacji pozamaterialnej są szansa na awans oraz możliwość rozwoju i doskonalenia umiejętności zawodowych (wykres 3). Obie odpowiedzi otrzymały po $29 \%$ wskazań. Pochwały słowne są skutecznym sposobem na motywację według $17 \%$ ankietowanych, udział w podejmowaniu decyzji - według $16 \%$ badanych, a na odpowiedź dotyczącą poszerzania zakresu obowiązków i odpowiedzialności wskazało 9\% pracowników. Pracownicy oczekują więc awansu w hierarchii przedsiębiorstwa oraz rozwijania swoich umiejętności.

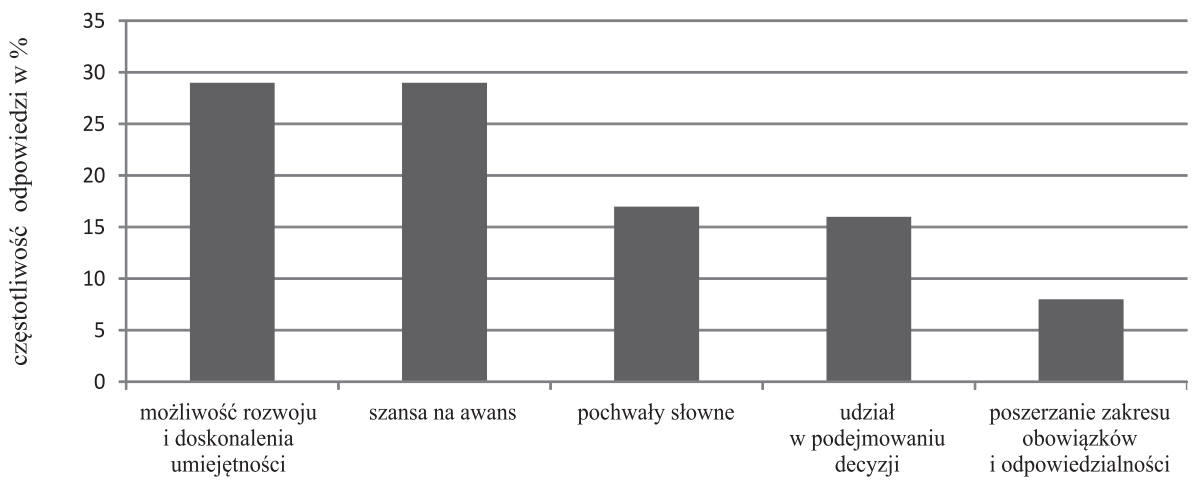

Wykres 3. Najważniejsze formy motywacji niematerialnej według badanych pracowników

Źródło: badania własne.

Formy motywowania niematerialnego stosowane w badanej firmie są zaprezentowane na wykresie 4 . Mimo tak szerokiego ich wachlarza $27 \%$ badanych nie dostrzega $\mathrm{w}$ firmie form motywowania niematerialnego. Czterech z dziesięciu pracowników otrzymało pochwały słowne (42\% odpowiedzi) i są one najczęściej dostrzeganym przez pracowników działaniem motywacyjnym. Taki wynik świadczy o dobrej komunikacji między przełożonymi a podwładnymi w firmie. Kierownicy często i chętnie korzystają z pochwał, co zostało dostrzeżone przez pracowników.

Szanse na awans, udział w podejmowaniu decyzji oraz poszerzanie zakresu obowiązków i odpowiedzialności dostrzega 8\% ankietowanych (wykres 4). Najrzadziej dostrzeganym działaniem pozafinansowym mającym na celu motywowanie pracowników jest możliwość rozwoju i doskonalenia umiejętności - 7\% wskazań. Pracownicy najbardziej z wszystkich form pozamaterialnej 
motywacji cenią sobie możliwość rozwoju oraz możliwość awansu. Wydaje się, że konieczne jest dopracowanie systemu motywacji pozafinansowej. Firma powinna częściej organizować szkolenia, kursy, zachęcać pracowników do poszerzania kompetencji, dalszej nauki przez opłacanie części lub całości kosztów kształcenia. Również częstszym zjawiskiem powinny być awanse pionowe, a każdy awans powinien być odpowiednio nagłaśniany wewnątrz firmy.

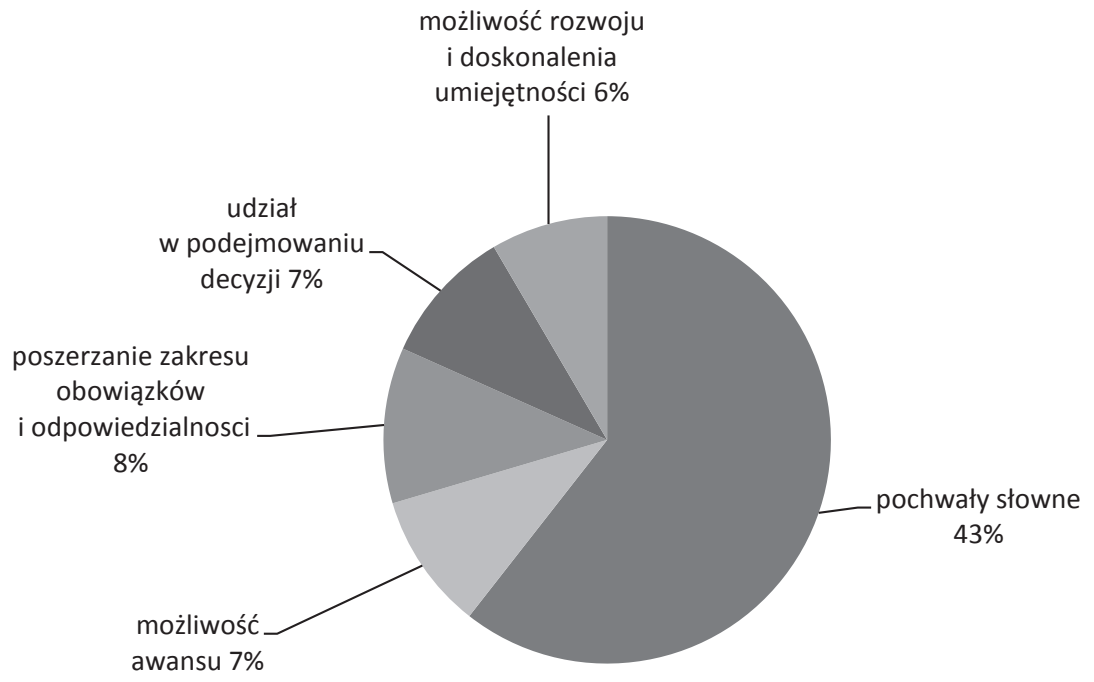

Wykres 4. Niematerialne formy motywacji stosowane w badanym przedsiębiorstwie Źródło: badania własne.

Zrozumienie pojęcia motywacji było treścią ostatniego pytania $\mathrm{w}$ ankiecie. Wyniki zostały zaprezentowane na wykresie 5. Największa liczba ankietowanych (36\% pytanych) motywację łączy z pieniędzmi i innymi korzyściami materialnymi. Motywację co trzeci z badanych rozumie jako praktyczne działanie pracodawcy, które pobudza do lepszej pracy. Dla co piątego z badanych motywacja to synonim dobrej komunikacji w miejscu pracy. Natomiast dla $12 \%$ badanych pracowników działania motywacyjne to indywidualne podejście do pracowników. Jedynie dla 4\% ankietowanych motywacja kojarzy się z pochwałami pracowników przez pracodawcę. Uzyskane odpowiedzi wskazują, że w badanym przedsiębiorstwie pracownicy wciąż uznają pieniądze za najlepszy środek motywacji. Mimo wzrastającej roli atmosfery w pracy, indywidualnego podejścia do pracowników, pobudzania ich do działania i po- 
chwał za dobre zachowania jednak pieniądze pozostają najskuteczniejszym instrumentem motywowania pracowników.

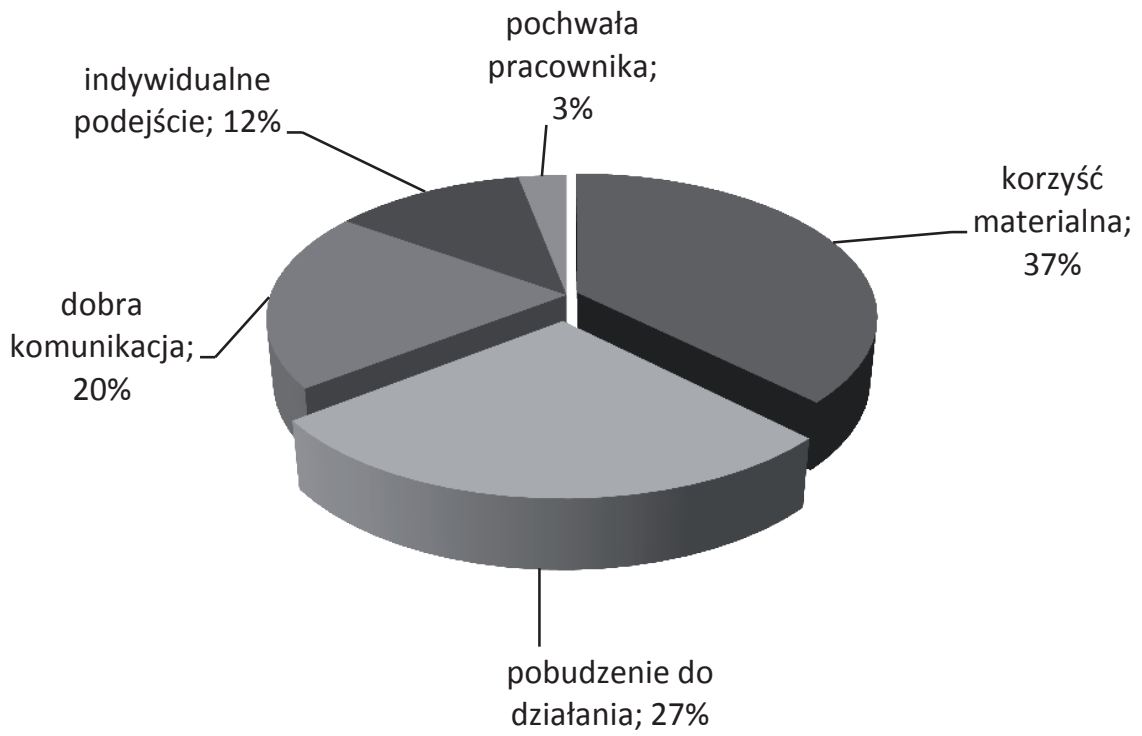

Wykres 5. Rozumienie pojęcia motywacji przez badanych pracowników Źródło: badania własne.

\section{PODSUMOWANIE}

Wyniki przeprowadzonych badań dowodzą, że istniejący system motywowania w firmie uważany jest za poprawny i skuteczny. Ankietowani wskazali na bardzo dobrą atmosferę w pracy - wszystkie ankietowane kobiety i 95\% objętych badaniem mężczyzn - oraz odpowiednio do oczekiwań skonstruowany system motywacji materialnej.

Przeprowadzone badania wykazały, że najskuteczniejszym motywatorem są pieniądze. Pracownicy pojęcie motywacji kojarzą przede wszystkim z korzyściami materialnymi - 36\% ankietowanych, dlatego też należy uznać je za najważniejszy czynnik motywujący. Podwyżka (44\%), udziały w korzyściach (19\%) czy zyskach(15\%) są najbardziej pożądanymi przez pracowników motywatorami. Wśród wartości niematerialnych niemałe znaczenie ma atmosfera w pracy. 
Zarówno relacje między pracownikami, jak i relacje miedzy przełożonymi a podwładnymi były w przedsiębiorstwie ważnym czynnikiem motywującym. Atmosferę można budować nie tylko codziennymi kontaktami w pracy, wspólne szkolenia, kursy, imprezy firmowe czy wyjazdy integracyjne znacznie podnoszą morale pracowników, budują więzi, zwiększają lojalność i stopień identyfikacji pracownika z firmą, w której jest zatrudniony.

\title{
LITERATURA
}

Bruce A., Pepitone J. (2001), Jak motywować pracowników, Wydawnictwo RM, Warszawa.

Gick A., Tarczyńska M. (1999), Motywowanie pracowników, PWE, Warszawa.

Gliszczyńska X. (1991), Poznawcze modele motywacji pracowników, PWN, Warszawa.

Karaś R. (2003), Teorie motywacji w zarządzaniu, Wydawnictwo Akademii Ekonomicznej w Poznaniu, Poznań.

Lubrańska A. (2008), Psychologia pracy, Wyd. Difin, Warszawa.

Machaczka J. (1999), Podstawy zarzadzania, Wydawnictwo Akademii Ekonomicznej w Krakowie.

Sikora J. (2000), Motywowanie pracowników, OPO, Bydgoszcz.

Zbiegień-Maciąg L. (1997), Motywacyjne aspekty wynagradzania pracowników, [w:] Jak skutecznie wynagradzać pracowników, K. Sedlak (red.), Wydawnictwo Profesjonalnej Szkoły Biznesu, Kraków.

\section{MOTIVATION AS A MANAGEMENT FUNCTION WITHIN THE COMPANY}

\begin{abstract}
A b stract. The structure of motives is always a hierarchical system. This means that some of the employees are appreciated more, some less. Created personal hierarchy of needs, different for each person because different people prefer different values, but people prefer the values that are most valued by them, while those that they consider the most realistic to accomplish in the article attempts to determine the value of the motivation system the audited company. For this purpose, a survey was conducted. Been conducted to determine the relationships which exist between the employees and the motivation factor tangible and intangible subjects are most important to employees.
\end{abstract}

K e y w o r d s: motivation, management, two-factor theory of F. Herzberg. 